\title{
Understanding the Economic Sustainability Model for Urban Rail Transit Operator: A TOD Perspective
}

\author{
Hong Zhang ${ }^{1}$, Yi Guo ${ }^{2, *}$ \\ ${ }^{1}$ Shenzhen Metro, Shenzhen, Guangdong, China \\ ${ }^{2}$ Shenzhen University, Shenzhen, Guangdong, China \\ *Correspondence Author,szguoyi@foxmail.com
}

\begin{abstract}
With the growth of urban rail transit construction and operation scales, it is necessary to strengthen and deepen the studies on urban rail transit enterprise economic sustainability model. From the theoretical and practical angles, this paper reviewed the exploration and practice process of urban rail transit enterprise economic sustainability model, including the connotation of "metro operation + property development" profit model, as well as further studies and prospect. It suggests TOD model can improve the economic sustainability capability of urban rail transit enterprise, and set up a self-virtuous development cycle in rail transit industry.
\end{abstract}

Keywords: Urban rail transit, Economic sustainability model, Metro operation, Property development, TOD.

\section{Overview of Urban Rail Transit Development}

With the increasing growth of population number and the acceleration of urbanization, the pressure on the urban transportation is rising. In order to reduce the pressure on traffic, countries around the world start to greatly develop the rail transit to decrease traffic congestion and urban pollution. The urban rail transit construction started early at abroad[1]. For example, megalopolis like London, New York, Moscow and Tokyo, have developed complete urban rail transit network by the end of 1990s[2]. As limited by technology and economy development, the China's urban rail transit construction only begun in the middle of 1990s. However, it stepped into skyrocketing development in the beginning of $21^{\text {st }}$ century. According to China Urban Rail Transit Association's information express in Issue 1, 2020, China's mainland 34 cities in total have completed $7700 \mathrm{~km}$ urban rail transit lines in operation by December $31^{\text {st }} 2020$. It is estimated that the urban rail transit will stay in fast development in future 5 years and its construction and operation will be expanded[3].

However, with the characteristics of large investment, long payback period, and public welfare pricing, the urban rail transit will have direct poor economic benefits. As a result, the overwhelming urban rail transit companies around the world have made losses; burden on the government is increasing; the private capital is inactive; and the urban rail transit enterprises are hard to realize their self-development. Therefore, the research on the urban rail transit enterprise profit model is urgent to be emphasized to help companies to have "selfhematopoietic" function and to achieve sustainable development.

\section{The Connotation and Development of Economic Sustainability Model}

\subsection{Theoretical Model}

The fundamental cause of urban rail transit enterprises' loss is that the huge positive externalities are not shared by the enterprises themselves. Hence how to internalize positive externalities as much as possible becomes the theoretical basis for constructing the profit model of urban rail transit. From the prospective of input and output, there are 4 major categories of urban rail transit construction and operational input, namely, the value of metro lines, ancillary resources, the added value of land that is not transferred and the properties along the line, and the added value of transferred land[4]. At present, urban rail transit enterprises have owned the first two categories, but not the last two that is several times output than the first two, and externalized or lost as not effectively used. It is not fair for urban rail transit enterprises, government and taxpayers. If the externalized output benefits of the last two categories can be returned to urban rail transit enterprises, it is helpful for the companies to build profit model. This profit model can be theoretically summarized as "Metro Management + Benefits Return".

For the ways of externalized output benefits to return, theoretically there are 4 at least as following:

(1) Return the added value benefits of land that is not transferred along the line. There are 2 ways to return the added value of the land. For the land that is suitable to develop metro superstructures (including underground space, the same below), the government can grant the urban rail transit enterprises the right through policies to make unified planning, unified development or return the right of development. Second, for the added value of land along the line within a scope of $500 \mathrm{~m}$, the government can return the added value of land to the rail transit enterprises at a certain percentage after bidding \& auction for the land[5].

(2) Partially return the added value benefits of the property and the transferred land along the rail transit line within a scope of $500 \mathrm{~m}$. For the part of added value benefits, in accordance with government policy, its return can be realized by returning tax of the land added value collected in the real estate transfer to the rail transit enterprises at a certain percentage in the principle of "decrease-by-distance"[6].

(3) Return the added value of developed property within 500 $\mathrm{m}$ to the rail transit station. For the part of added value benefits, in accordance with government policy, its return can be realized by imposing a certain fee to return to the rail transit 
enterprises in the principle of "decrease-by-distance" based on the fact that the developed property's distance to the station. If the cost is calculated by the property area, a certain fee will be charged per added unit area[7].

(4) Return the benefits that earned by the improvement of urban ground traffic after rail transit's development. This part of benefits, in accordance with government policy, can be realized by imposing a certain fee on the users except the pedestrian and public transport service users to return to the rail transit enterprises at a certain percentage in the principle of "user's fees"[8].

\subsection{Application Model}

Although the externalized output benefits in the profit mode "Metro Management + Benefits Return" can be theoretically returned through the above 4 ways. However, the last 3 ways are directly involve private interests. In consideration of policy and implementation, the last 3 ways are not recommended at present stage. The first way that returns the externalized output benefits to the rail transit enterprises is suggested here[9]. Specifically, it means that granting the right of developing the metro superstructures and the land that is not transferred along the line to the rail transit enterprises, which carry out integrated planning and design, overall consider rail transit construction and property development, and returns benefits of property development to rail transit construction, so as to realize the partial internalization of the huge external benefits of rail transit. In view of the above, based on the profit model's ("Metro Management + Benefits Return") specific application, it is summarized as the profit mode "Metro Management + Property Development". In this model, the main profits come from the real estate development benefits (including the added value benefits and property development profit arising from its reinvestment) and property rent from the management and property's appreciation[10].

\section{The Effectiveness of Profit Model "Metro Management + Property Development"}

\subsection{The Municipal Government's Decision on Developing Metro Property}

In August 2007, the municipal government clarified that the land income of superstructure property and profits from development will be specially used for rail transit construction and loss-compensation for operation; in November, 2008, city government passed a decision that the development of tophead estates can consider the method of packing that is implemented by Shenzhen Metro. All earnings from the development of top-head estates will be used for rail transit construction and loss-compensation for operation. In March, 2012, the municipal government clarified that the legal effect of land-use right acquired by capital contribution equals to that acquired by transferring. In February, 2013, the municipal government required a reasonable definition of government responsibility and corporate responsibility. The related government departments shall provide policy support for Shenzhen rail transit construction and perform the duty of supervision; the government also passed a decision that prepare the land financing planning and dynamically allocate land recourses in accordance with Shenzhen rail transit construction's need.

\subsection{Shenzhen Metro's Land Resources for Property Development and Its Partial Added Value Benefits}

In June, 2008, Shenzhen Metro successfully competed for the right of real estate development of $1,400,000 \mathrm{~m}^{2}$ Depot in Qianhaiwan through directed bidding and auction, in which the commercial developing area occupies $800,000 \mathrm{~m}^{2}$ and affordable housing developing area occupies $600,000 \mathrm{~m}^{2}$. After assessment, it is confirmed that the added value benefits (positive externalities) earned by the $39.2 \%$ of total land price will return to Shenzhen Metro.

In 2020, Shenzhen Metro again successfully competed for the $522,000 \mathrm{~m}^{2}$ real estate land in Tanglang Depot, Shekou West Station, Shenzhen University Station, and Shenzhen North Station through directed bidding and auction. After Shenzhen Metro's payment for the land price, the municipal government returned the land price to Shenzhen Metro as its registered capital for metro construction. All benefits from the development will be reserved for Shenzhen Metro for repaying capital and interest of metro construction loans, and for rail transit construction and loss-compensation for operation.

In 2012, the municipal government granted the right of developing 2,175,000 $\mathrm{m}^{2}$ real estate land in Qianhai Hub, Henggang Depot and Shenwan Station to Shenzhen Metro. The land price after assessed will be invested to Shenzhen Metro as the project capital of metro construction. All benefits from the development will be reserved for Shenzhen Metro for repaying capital and interest of metro construction loans, and for rail transit construction and loss-compensation for operation.

For the property developing, by the end of 2017, Shenzhen Metro had 12 projects with developing right, including residential property, apartment, office, commercial property, hotel, etc. Shenzhen Metro's projects spread over several important developing areas in Shenzhen, reaching $4,500,000 \mathrm{~m}^{2}$ in total construction area and 100 billion yuan in estimated total earnings (land price + profits). The developed products started to go to market in succession from the year of 2013. Many projects, like Shanhaijin, Qianhai Era, Tanglang City, Shanhaiyun and Jinhui PARK, were successively launched. They received promising market response and earned well industry reputation.

With regard to the project developing model, Shenzhen Metro, after repeated comparison of different property developing models and developing plans, initially clarified the diversified one for the real estates which is independently developed and coexists different developing models in consideration of factors, like project's realization, capital withdrawal requirements, and project's complexity, economic benefits and market risks. Currently, the overwhelming projects of Shenzhen Metro adopt cooperative development as seeking for the partner's strength and brand effect[11]. Thus the goal that the acceleration of going to market, the withdrawal of capital, and the improvement of developing benefits can be realized. Except the independent development, the developed 
cooperative ways by Shenzhen Metro include legal person cooperation, agreement type cooperation, agent development cooperation, etc.

\section{3 "Metro Management + Property Development" Model's Supporting Effect on Investment and Financing}

The implementation of profit model "Metro Management + Property Development" provides a promising financial expectation for Shenzhen Metro's future. Supported by Shenzhen municipal government and relevant departments, Shenzhen Metro's financing achieved fruitful results.

For supporting the construction of project phase 1 and project phase 2 of Shenzhen Metro, a syndicated loan amounting to 59.8 billion yuan was successfully established on unsecured and unsecured corporate credit, and on a $10 \%$ discount benchmark interest rate. From 2011 to 2013, a five-year medium-term note with 10 billion yuan was successfully issued in three batches on a $14.69 \%$ discount benchmark loan interest rate lower than that at same period. From 2013 to 2014 , 8 billion yuan of corporate bonds were successfully issued in two batches on a $9.83 \%$ discount benchmark loan interest rate lower than that over the same period. From 2014 to 2013, a short-term financing bill of 12 billion yuan was issued by batches on a $10.34 \%$ discount benchmark loan interest rate lower than that over the same period; from 2016 to 2015, a super short-term financing bill of 5 billion yuan was issued by batches. In September 2014, Shenzhen Metro Qianhai International Development Co., Ltd., a subsidiary company of Shenzhen Metro, served as a platform to take advantages of the low cost of Hong Kong RMB and successfully developed the cross-border RMB loan business in Qianhai. At present, there are two cross-border RMB loans in total of 1.6 billion yuan that have been successfully operated. Compared to the domestic bank loan interest rate over the same period, the financing cost was saved about 84 million yuan.

\section{The Further Study and Prospect of Urban Rail Transit Profit Model}

In order to expand the profit space of urban rail enterprises, on the basis of profit model "Metro Management + Property Development", Shenzhen Metro linked the industrial characteristics of quasi-public product and positive externalities, high valued assets and low earnings, and scale economy and scope economy to deepen the research on the profit model of urban rail enterprises.

Guided by the profit model "Metro Management + Property Development", enterprises shall continue to operate metro business well, and actively promote the development of property so as to create more high-end and high-quality real estate projects for returning earnings to metro operation.

By making full use of metro passengers as key resources, enterprises shall promote carrying out the earning model "Member + Fund". Enterprises shall take the metro stored value card as the carrier and developed car holder into members. Meanwhile, they should strengthen the card's function of investment and financing by learning from Yu'ebao's model of Internet financing, encourage members to increase the card's capital deposit, and set up metro industrial investment fund by the above deposit for metro construction, property development, and purchase or hold the high-quality metro business and property.

According to the theory of scope economy, enterprises shall fully exploit the virtual economy and actively explore the profit model "Entity + Virtual". As the mobile public space, the subway naturally matches to the mobile Internet. For example, covering WiFi signals within the metro space and developing third-party applications (Metro APP). In consideration of the passenger flow per day in subway and their average staying time, more earnings can be realized for enterprises.

Exploring capital operation on the basis of "Metro Management + Property Development". For promoting the implementation of rail transit enterprises' profit model, expanding their earning sources, and enhancing their selfsurvival and development, Shenzhen Metro, after implementing the above model, carried out a beneficial trial to realize enterprises' sustainable development by the capital market. In 2017, Shenzhen Metro took use of the fund accumulated in the past years, meanwhile, transferred prescribed proportion of merger and acquisition loans to Vanke A-share held by China Resources and Evergrande, becoming the largest shareholder of Vanke. Afterwards, Shenzhen Metro will start the new developing model "Metro Management + Property Development + Capital Operation" which will boost capitalization and securitization for Shenzhen Metro's assets and enhance controlling the stateowned capital and preservation and increment of state-owned assets.

\section{Conclusion}

Based on the implementation and preliminary effect of the above projects exporting operation and maintenance technology, in the perspective of practice, the profit model can be summarized as "Metro Management + Property Development + Capital Operation + Technology Export". Shenzhen Metro is also exploring the virtual economy through membership of mobile Internet and E-commerce.

After years' study, exploration and practice, Shenzhen Metro's assets are continually expanding with increasing diversified income sources and growing earning ability. In future, Shenzhen Metro will continue to deepen study and explore the economic sustainability model for rail enterprises, improve the earing ability, and further enhance enterprises' sustainable development in self-positive succession.

\section{References}

[1] Carlton, I. (2019). Transit Planners' Transit-Oriented Development-Related Practices and Theories. Journal of Planning Education and Research, 39(4), 508-519.

[2] Delpirou, A., Doulet, J.-F., Delaunay, T. (2016). Why Research on TOD in China have Helped Pinpoint Key Challenges for a Better Integration between Urban and Transportation Planning? A Critical Review of the Literature. Journal of Transport and Land Use. 
[3] China Urban Rail Transit Association. Overview of Urban Rail Transit Routes in China in 2020. China Urban Rail Transit Association, 2021(1), 1.

[4] Loo, B. P. Y., Du Verle, F. (2017). Transit-oriented Development in Future Cities: Towards a Two-level Sustainable Mobility Strategy. International Journal of Urban Sciences, 21(sup1), 54-67.

[5] Hong Z, Yong L, Jianguang X. (2007). Research on Urban Rail Transit Profit-Making Model Based on Sustainable Development. Urban Rapid Rail Transit, 5: 9.

[6] Hong Z, Yong L, Sanxi D. (2007). Experiences of Investment/Financing on Metro in Seven World Cities. Urban Rapid Rail Transit, 10: 6.

[7] Xiaoli Z, Hong Z, Yong L. (2008). Connotation and Idea of Operation of an Earning Model-"Metro Management + Property Development". Urban Rapid Rail Transit, 2: 1.

[8] Hong Z. (2012). On Investment and Financing Models of Urban Rail Transit Marketing. Economist, 10: 101.

[9] Hong Z. (2015). On Profit Model of Metro Enterprises Based on Quasi-marketization Principle. Urban Mass Transit, 18 (8): 1.

[10] Lyu, G., Bertolini, L., Pfeffer, K. (2016). Developing a TOD Typology for Beijing Metro Station Areas. Journal of Transport Geography, 55, 40-50.

[11] Zhang, M. (2007). Chinese Edition of Transit-Oriented Development. Transportation Research Record: Journal of the Transportation Research Board, 2038(1), 120-127. 